\title{
Medium-term effect of perennial energy crops on soil organic carbon storage
}

\author{
Enrico Ceotto, Mario Di Candilo \\ CRA-CIN Centro di Ricerca per le Colture Industriali, Bologna, Italy
}

\begin{abstract}
The scope of this study was to evaluate the effect of perennial energy crops on soil organic carbon (SOC) storage. A field experiment was undertaken in 2002 at Anzola dell'Emilia (Bologna), in the lower Po Valley, Northern Italy. Five perennial energy crops were established on a land area which had been previously cultivated with arable crops for at least 20 years. The compared crops are: the herbaceous perennials giant reed and miscanthus, and the woody species poplar, willow and black locust, managed as short rotation coppice (SRC). SOC was measured in 2009 , seven years after the start of the experiment, on an upper soil layer of 0.0-0.2 $\mathrm{m}$ and a lower soil layer of $0.2-0.4 \mathrm{~m}$. The study aimed to compare the SOC storage of energy crops with alternative land use. Therefore, two adjacent areas were sampled in the same soil layers: i) arable land in steady state, cultivated with rainfed annual crops; ii) natural meadow established at the start of the experiment. The conversion of arable land into perennial energy crops resulted in SOC storage in the upper soil layer $(0.0-0.2 \mathrm{~m})$ ranging from 1150 to $1950 \mathrm{~kg} \mathrm{C} \mathrm{ha}^{-1}$ year-1 during the 7-year period. No significant differences were detected in SOC among crop species. We found no relationship between the harvested dry matter and the SOC storage. The conversion of arable land into perennial energy crops provides a substantial SOC sequestration benefit even when the hidden $\mathrm{C}$ cost of $\mathrm{N}$ industrial fertilizers is taken into account. While the SOC increased, the total $\mathrm{N}$ content in the soil remained fairly constant. This is probably due to the low rate of nitrogen applied to the perennial crops. However, our data are preliminary and the number of years in which
\end{abstract}

Correspondence: Enrico Ceotto, CRA-CIN Centro di Ricerca per le Colture Industriali, via di Corticella 133, 40128 Bologna, Italy.

Tel. +39.051.6316845 - Fax: +39.051 .374857 .

E-mail: enrico.ceotto@entecra.it

Key words: soil organic carbon sequestration, energy crops, herbaceous perennial, woody species.

Acknowledgments: the present study was funded by the Bioenergie and Suscace projects, financed by the Ministry of Agricultural, Food and Forestry Policies of Italy. The authors owe their thanks to the editor and the reviewers for comments and suggestions that considerably improved the first version of the manuscript.

Received for publication: 23 February 2011.

Accepted for publication: 6 October 2011.

(ㄷ) Copyright E. Ceotto and M. Di Candilo, 2011

Licensee PAGEPress, Italy

Italian Journal of Agronomy 2011; 6:e33

doi:10.4081/ija.2011.e33

This work is licensed under a Creative Commons Attribution NonCommercial 3.0 License (CC BY-NC 3.0). the SOC continues to increase needs to be quantified, especially for the herbaceous species giant reed and miscanthus, with a supposedly long duration of the useful cropping cycle of 20 years or longer.

\section{Introduction}

Many nations have formulated policies promoting the production and use of biomass to generate heat, power and liquid transport fuels (FA0, 2008). These policies were boosted by the perspective of the depletion of oil reserves and the concerns about energy security and global climate change (Koh and Ghazoul, 2008). Nonetheless, there is an intense debate in the scientific literature over the advantages and disadvantages of using cropland for producing biomass for energy. Some scientists, but certainly not all, believe that energy crops have a positive effect on the mitigation of $\mathrm{CO}_{2}$ emissions (Payne, 2010). Other authors have advised against the undesired effects of a widespread diffusion of energy crops on the global carbon cycle (Crutzen $e t$ al., 2008; Fargione et al., 2008; Searchinger et al., 2008). Two major aspects need to be considered when assessing the contribution of energy crops on meeting future energy demand with limited environmental impact: i) the amount of fossil energy that is required to produce each unit of renewable energy; ii) the greenhouse gas (GHG) emissions that are released in the process (Liebig et al., 2008). Therefore, the amount of soil organic carbon (SOC) released by or sequestrated into the soil is a crucial component of the life cycle analysis (LCA) of energy crops (Anderson-Texeira et al., 2009). LCA is a system analysis tool that provides information on the full environmental effects of a product, service or system from its cradle (extraction of raw materials) to its grave (management of waste). Until now, only a few LCA studies on energy crops have considered the change in SOC (Brandão et al., 2011). Indeed, producing biomass for energy and SOC storage are often regarded as conflicting land-use options for the mitigation of climate change (Rootzen et al., 2010; Righelato and Spracklen, 2007). On the one hand, annual grain crops, notably maize (Zea mays L.) and soybean (Glicine Max (L.) Merr.), when devoted to produce biofuels, are poorly suited to improve carbon cycling because they require annual tillage and high agronomic input for nitrogen fertilization and pest control, which implies high greenhouse gas emissions from fossil energy sources (Farrel et al., 2006). On the other hand, perennial lignocellulosic crops have the potential to provide a range of benefits for both ecosystem services and SOC storage compared with arable land (Rowe et al., 2009). Perennial plants, grown on soils poorly suited for grain production, were suggested to maximize the reduction of GHG emission of energy crops (Crutzen et al., 2008; Tilman et al., 2009). In literature there is a general consensus that the conversion of arable land to perennial energy crops will result in SOC storage, while the conversion of permanent grassland into perennial energy crops might not be as beneficial (King et al., 2004; Rowe et al., 2009). Several studies addressed SOC sequestration with short rotation systems (Grigal and Berguson, 1998; King et al., 2004), while others considered the effect of herbaceous perennials (Bransby et al., 
1998; Liebig et al., 2008). Nevertheless, to our knowledge, no studies have yet compared the effect of woody and herbaceous perennial crops on SOC storage at the same location. There is, then, an increasing need to quantify the amount of SOC that might be stored in soil profiles with diverse energy land-use options.

Long-running field experiments, with permanent plots extended over years, are extremely useful to provide an insight into soil processes subject to change over decades, like SOC dynamics and soil fertility itself. (Richter et al., 2007).

The scope of this study was to assess the SOC storage of woody and herbaceous perennial energy crops.

\section{Materials and Methods}

\section{Site characterization and agronomic details}

A field experiment was undertaken in 2002, and is still ongoing, at the CRA-CIN station at Anzola dell'Emilia (Bologna), in the lower Po Valley, Northern Italy $\left(44^{\circ} 32^{\prime} \mathrm{N}, 11^{\circ} 80^{\prime} \mathrm{E}, 38 \mathrm{~m}\right.$ a.s.l.). The soil of the site is loam-silty, classified as Udifluventic Haplustepts fine silty, mixed mesic (Soil Survey Staff, 2003). The main physical and chemical characteristic of the soil are reported in Table 1. The location is characterized by an annual average precipitation of about $600 \mathrm{~mm}$. The climate is temperate sub-continental, due to the long distance (approximately $200 \mathrm{~km}$ ) from the sea.

The following lignocellulosic crops are compared: two herbaceous perennials, giant reed (Arundo donax L.) and miscanthus (Miscanthus $x$ giganteus hybrid); and three woody perennials, managed as short rotation coppice, poplar (Populus $x$ canadensis hybrid), willow (Salix alba L.) and black locust (Robinia pseudoacacia L.). The herbaceous perennials were harvested every year, while the SRC were harvested every two years. The herbaceous perennial giant reed and miscanthus were fertilized annually with $120 \mathrm{~kg} \mathrm{~N} \mathrm{ha}^{-1}$, applied in the form of urea, $+120 \mathrm{~kg} \mathrm{P}_{2} \mathrm{O}_{5} \mathrm{ha}^{-1}$, applied in form of superphosphate; the SRC of poplar and salix were fertilized every two years, after each harvest, with $120 \mathrm{~kg} \mathrm{~N} \mathrm{ha}^{-1}$ in the form of urea $+120 \mathrm{~kg} \mathrm{P}_{2} \mathrm{O}_{5} \mathrm{ha}^{-1}$; and the SRC of black locust, a legume species, receives zero nitrogen $+120 \mathrm{~kg}_{2} \mathrm{O}_{5}$ ha $^{-1}$ every two years, after each harvest.

The perennial crops were only irrigated during the summer of the first year, with three irrigations of $30 \mathrm{~mm}$ during the season, with the aim of facilitating crop establishment. In the subsequent years, the experiment was not irrigated. Weeds were controlled mechanically during the first year of crop establishment. Insect populations were controlled chemically in poplar and willow. The experimental design was a randomized block with four replications. The dimension of each individual plot was $40 \mathrm{~m}^{2}$. Owing to budget limitations, only the first three replications were sampled to measure SOC.

Before starting the experiment, the land area had been cultivated with annual arable crops for at least 20 years. In fact, the dairy farm activities at the experimental station ceased in 1980. Therefore, no alfalfa meadows have been cultivated and no livestock manure has been applied to the soil since then.

Unfortunately, the SOC was not measured at the start of the experiment, because the initial scope of the field trial was to evaluate biomass productivity and qualitative characteristics of the investigated crops. However, the presence of adjacent areas with alternative land use, namely arable land in steady state, and arable land converted into a natural meadow, allowed the SOC for alternative options of land use to be evaluated. We then measured the SOC of the five crops and adjacent areas in February 2009, seven years after the start of the experiment. At the beginning of the experiment, a permanent meadow was allowed to establish on a contiguous strip within the field. The mead- ow gradually evolved into a stable association between grass and white ladino clover (Trifolium repens L.). The meadow was mowed twice a year, at the end of May and at the end of September. The aboveground biomass was finely cut and left on the soil surface. The meadow was not fertilized. This provided the opportunity to assess the SOC storage as influenced by a permanent meadow in which nitrogen was entering the ecosystem via symbiotic fixation. Moreover, an adjacent area, cultivated with rainfed arable crops, i.e. grain sorghum (Sorghum bicolor (L.) Moench), wheat (Triticum vulgare L.) and sugarbeet (Beta vulgaris $\mathrm{L}$. var. saccharifera), was used as control for SOC content. Crop residues of sorghum and sugarbeet were returned to the soil, while wheat straw was baled and removed from the soil. Three replications of soil samples were also collected on the two adjacent areas cultivated with the permanent meadow and the arable land. We hypothesized that soil cultivated with arable crops was in a steady state for SOC, while the land use change deriving from the conversion of arable land to energy crops, and the conversion to permanent meadow, could result in SOC sequestration. The same approach was used by Hansen et al. (2004). Working in Denmark, these authors compared the SOC of a 9- and a 16-year old miscanthus plantation with those of adjacent areas with grassland and arable row crops. Similarly, Kahle et al. (2001), working in Germany, compared the SOC of miscanthus with that of adjacent grassland.

\section{Soil sampling and analysis}

Soil samples were collected from all plots on 25 February 2009, about seven years after the start of the experiment. For each plot, five independent soil cores were collected at a distance of about $0.5 \mathrm{~m}$, for the soil layers 0.0-0.2 m and 0.2-0.4 m. Soil cores were collected using a 7 cm diameter soil sampler drill, model Eijkelkamp. The five cores of each plot were combined in one sample and sieved. The sieved soil was used to determine the organic $\mathrm{C}$ through chromic acid digestion, according to the Walkley-Black method and total $\mathrm{N}$ using the Kjeldahl method, according to Page et al. (1982). A soil bulk density of $1.663 \mathrm{Mg} \mathrm{m}^{-3}( \pm$ 0.04 ) was determined by collecting undisturbed soil samples using cylinders of $98 \mathrm{~cm}^{3}$ pressed horizontally into the soil. This value of bulk density was used to calculate the amount of organic carbon per unit soil. The annual carbon gain was calculated as the difference between the average value of SOC of individual treatments and the average value of SOC for the arable land, divided by the number of years from the start of the experiment.

Table 1. Chemical and physical characteristics of the soil.

\begin{tabular}{|c|c|c|}
\hline & \multicolumn{2}{|c|}{ Soil layer (m) } \\
\hline & $0-0.2$ & $0.2-0.4$ \\
\hline Sand, (g/100g) & 24 & 25 \\
\hline Silt, $(g / 100 g)$ & 55 & 55 \\
\hline Clay, (g/100g) & 21 & 20 \\
\hline Field capacity, (\% vol.) & 32 & 31 \\
\hline Wilting point, (\% vol.) & 22 & 21 \\
\hline Porosity, (\% vol.) & 37 & 37 \\
\hline Bulk density, (Mg m-3) & 1.663 & 1.663 \\
\hline $\mathrm{pH}\left(\right.$ in $\left.\mathrm{H}_{2} \mathrm{O}\right)$ & 8.18 & 8.28 \\
\hline $\mathrm{CaCO}_{3}$ total, $(\mathrm{g} / 100 \mathrm{~g})$ & 20 & 21 \\
\hline $\mathrm{CaCO}_{3}$ active, $(\mathrm{g} / 100 \mathrm{~g})$ & 3.25 & 3.87 \\
\hline $\mathrm{N}$ total (Kjeldahl), (g/1000 g) & 1.12 & 1.50 \\
\hline Organic matter (Walkey \& Black), (g/100 g) & 1.05 & 1.28 \\
\hline P available (Olsen), (mg/kg) & 15.8 & 10.2 \\
\hline K exchangeable, (mg/kg) & 180 & 193 \\
\hline $\mathrm{CSC},(\mathrm{mq} / 100 \mathrm{~g})$ & 10.7 & 11.1 \\
\hline
\end{tabular}




\section{Statistical analysis}

The analysis of variance (ANOVA) of SOC data was performed using the GLM procedure of the SAS systems (SAS, 1989). Since we compared the SOC of the five treated crops in permanent meadow and arable soil, not initially included in the experimental design, in ANOVA analysis we treated data as from a completely randomized experimental design. Selected contrasts were calculated to assess the significance of differences in SOC storage between specific combinations of land use. The relationship between SOC and soil nitrogen content, and between harvested dry matter yield and SOC, were evaluated using the PROC REG of the SAS systems (SAS, 1989).

\section{Results and Discussion}

\section{Soil organic carbon content}

The average values of SOC content, and the annual $\mathrm{C}$ gain, for the soil layers $0.0-0.2 \mathrm{~m}$ and $0.2-0.4 \mathrm{~m}$, are reported in Table 2 . The conversion of arable land into perennial energy crops resulted in SOC storage; in the upper soil layer $0.0-0.2 \mathrm{~m}$, ranging from 1150 to $1950 \mathrm{~kg} \mathrm{C} \mathrm{ha}^{-1}$ $\mathrm{y}^{-1}$ during a 7 -year period. No significant differences were detected among crop species. Our findings are consistent with Bransby et al. (1998) who reported that perennial grasses in the US Midwest added to the soil upper meter about $1100 \mathrm{~kg} \mathrm{C} \mathrm{ha}^{-1}$ year-1 for a 5 -year period.

Compared to the arable land, the SOC of the 0.0-0.2 m layer was $+48 \%$ for willow, $+42 \%$ for both giant reed and poplar, $+28 \%$ for black locust and miscanthus, and $+19 \%$ for permanent meadow. However, only the SOC of willow, giant reed and poplar are statistically different from the SOC of arable land $(\mathrm{P}<0.05)$, while miscanthus and black locust are significantly different from arable land $(\mathrm{P}<0.1)$. The annual

Table 2. Soil organic carbon and annual $\mathrm{C}$ gain in the soil layers 0.0-0.2 $\mathrm{m}$ and 0.2-0.4 $\mathrm{m}$. The apparent average gain was estimated as a difference between soil organic carbon of individual treatments and the value of arable land. Means sharing common letters are not statistically different for $\mathbf{P} \leq \mathbf{0 . 0 5}$ (LSD). In the ANOVA table the value of probability is shown when $P<0.10$.

\begin{tabular}{|c|c|c|c|}
\hline Soil layer & $\begin{array}{l}0.0-0.2 \mathrm{~m} \\
\text { SOC Annual C gain } \\
\begin{array}{cc}\mathrm{Mg} \mathrm{C} & (\mathrm{kg} \mathrm{C} \mathrm{ha-1} \\
\left.\mathrm{ha}^{-1}\right) & \left.\mathrm{y}^{-1}\right)\end{array}\end{array}$ & $\begin{array}{l}0.2-0.4 \mathrm{~m} \\
\mathrm{SOC} \\
(\mathrm{Mg} \mathrm{C} \\
\left.\mathrm{ha}^{-1}\right)\end{array}$ & $\begin{array}{l}\text { Annual C gain } \\
(\mathrm{kg} \mathrm{C} \mathrm{ha-1} \\
\left.\mathrm{y}^{-1}\right)\end{array}$ \\
\hline \multicolumn{4}{|l|}{ Species } \\
\hline Willow & $39.40^{\mathrm{a}}$ & $31.03^{\mathrm{a}}$ & 585 \\
\hline Giant reed & $37.68^{\mathrm{a}}$ & $27.33^{\mathrm{ab}}$ & 63 \\
\hline Poplar & $37.63^{\mathrm{a}}$ & $27.80^{\mathrm{ab}}$ & 126 \\
\hline Miscanthus & $34.03^{\mathrm{ab}}$ & $26.03^{b}$ & -126 \\
\hline Black locust & $33.87^{\mathrm{ab}}$ & $27.67^{\mathrm{ab}}$ & 111 \\
\hline Meadow & $31.65^{\mathrm{ab}}$ & $28.20^{\mathrm{ab}}$ & 190 \\
\hline Arable land & $25.78^{b}$ & $26.90^{\mathrm{ab}}$ & 0 \\
\hline ANOVA & $\mathrm{P}>\mathrm{F}$ & $\mathrm{P}>\mathrm{F}$ & \\
\hline Crops & 0.08 & ns & \\
\hline \multicolumn{4}{|l|}{ Selected contrast } \\
\hline Arable land $u s$ crops & 0.006 & ns & \\
\hline Meadow us crops & ns & ns & \\
\hline Willow us arable land & 0.006 & 0.095 & \\
\hline Giant reed $v$ s arable land & 0.013 & ns & \\
\hline Poplar vs arable land & 0.014 & ns & \\
\hline Miscanthus vs arable land & 0.067 & ns & \\
\hline Black locust us arable land & 0.072 & ns & \\
\hline Willow vs meadow & 0.083 & ns & \\
\hline
\end{tabular}

$\mathrm{C}$ gain that we estimated for poplar in the present experiment, around $1690 \mathrm{~kg} \mathrm{C} \mathrm{ha}^{-1}$ year-1, are in good agreement with Grigal and Berguson, (1998). On the basis of a study on a poplar plantation conducted in the USA, the authors suggest that after an initial period of loss, carbon sequestration can be expected at the rate of $1000-1600 \mathrm{~kg} \mathrm{C} \mathrm{ha}^{-1}$ year-1, over a 10-15 year period. Moreover, the annual $\mathrm{C}$ gain that we estimated for miscanthus, about $1180 \mathrm{~kg} \mathrm{C}^{-1}$ year-1, are consistent with Hansen et al. (2004) who indicated an annual soil $\mathrm{C}$ gain with miscanthus in Denmark of between 780 and $1130 \mathrm{~kg} \mathrm{C}^{-1}$ year-1.

Although the SOC storage of perennial crops tends to be higher compared to permanent meadow, in most of the cases these differences are not statistically significant. Only the comparison between willow and permanent meadow was significant $(\mathrm{P}<0.1)$. The SOC of the $0.2-0.4 \mathrm{~m}$ layer remained quite constant regardless of the land use. Interestingly, only willow significantly raised SOC storage, compared to arable soil, in the 0.2-0.4 $\mathrm{m}$ soil layer $(\mathrm{P}<0.1)$.

The SOC accumulated after seven years of willow cultivation, 39.4 $\mathrm{Mg} \mathrm{C} \mathrm{ha} \mathrm{C}^{-1}$ in the soil profile $0.0-0.2 \mathrm{~m}$, is close to that reported for a bamboo stand (Bambusa spp.) in India; $42.1 \mathrm{Mg} \mathrm{C} \mathrm{ha}^{-1}$ (Nath et al., 2009) for the same soil layer. However, the cumulative carbon stock for willow in the soil profile up to $0.4 \mathrm{~m}$, i.e. $70.4 \mathrm{Mg} \mathrm{C} \mathrm{ha}^{-1}$, is distinctly lower than the value of $82.4 \mathrm{Mg} \mathrm{C} \mathrm{ha}^{-1}$ observed in Lodi, Lombardy, Northern Italy, after ten years of annual application of $66 \mathrm{Mg}$ farmyard manure ha ${ }^{-1}$ (Ceotto et al., 2006). However, it is important to note that in the case of farmyard manure, the crop residues used in composting farmyard manure were produced by external land areas. Consequently, farmyard manure application is likely to increase SOC at the expense of a larger land area providing crop residues (Tomasoni et al., 2011).

In literature, there is a general consensus that SOC is the result of the interaction between climate, vegetation and soil management. Therefore, several factors could have played a contributory role in the observed SOC storage:

- the prolonged canopy cover of the perennial crops and the presence of surface mulch could have determined favorable microclimatic conditions. In fact, SOC tends to increase with a decrease in mean temperature and with an increase in precipitation (Grigal and Berguson, 1998);

- SOC oxidation via microbial activity tends to decrease in the conversion to zero tillage due to lower soil $\mathrm{O}_{2}$ (King et al., 2004);

- the amount of biomass not harvested and returned to the soil, its above- to below-ground allocation, and the nature of organic compound that are produced (Grigal and Berguson, 1998).

Overall, the amount of SOC sequestration determined by the conversion from arable land to perennial crops with zero tillage is at first sight impressive. Nevertheless, it is quite obvious that the SOC storage cannot be maintained at the initial rate indefinitely (King et al., 2004). In literature, there is no consensus about the number of years necessary to reach a new equilibrium. Estimates vary from only six years (Paustian et al., 1997), to 10-15 years (Grigal and Berguson, 1998), up to $15-20$ years (West and Post, 2002).

\section{The hidden carbon costs of nitrogen fertilization}

While the benefits of increasing SOC on soil fertility, water retention and crop production are undisputed, some authors have expressed caution about the real benefit of SOC storage on global C cycle (Schelsinger, 1999; Schelsinger, 2000; Olness et al., 2002). In particular, Schelsinger (2000) argued that the SOC stored is often higher in fertilized fields, but this carries a hidden $\mathrm{C}$ cost that should be considered in evaluating the overall benefit in terms of global $\mathrm{C}$ balance.

Schlesinger (1999) indicated a factor of 1.436 moles of $\mathrm{CO}_{2}-\mathrm{C}$ released per mole of nitrogen when accounting for the full carbon cost of industrial nitrogen fertilizer, including manufacture, transport and 
application. Taking into account the ratio $\mathrm{C}$ to $\mathrm{CO}_{2}$, i.e. $12 / 44=0.27$, such an amount results in $1.436 / 0.27=5.32 \mathrm{~kg} \mathrm{CO} 2$ per kg N. Moreover, according to Crutzen et al. (2008) when $1 \mathrm{~kg}$ of nitrogen is supplied to a field crop, about $3-5 \%$ is released, sooner or later along the $\mathrm{N}$ cycle, in the atmosphere in the form of $\mathrm{N}_{2} \mathrm{O}$, a potent greenhouse gas with a global warming potential $(\mathrm{GWP})=296$, in $\mathrm{CO}_{2}$ equivalents. We here assumed the average value of $4 \%$ emissions, then $40 \mathrm{~g} \mathrm{~N}-\mathrm{N}_{2} \mathrm{O}$ emitted per kg of nitrogen applied; $\mathrm{N} / \mathrm{N}_{2} \mathrm{O}=0.636$, hence $40 / 0.636=62.9 \mathrm{~g} \mathrm{~N}_{2} \mathrm{O}$ x $296\left(\mathrm{CO}_{2}\right)=18616 \mathrm{~g}$, i.e. $18.6 \mathrm{~kg} \mathrm{CO}$ per $\mathrm{kg} \mathrm{N}$. Such an amount should be added to the $5.32 \mathrm{~kg} \mathrm{CO}$ per $\mathrm{kg} \mathrm{N}$ mentioned before to obtain an overall amount of $23.92 \mathrm{~kg} \mathrm{CO}$ per $\mathrm{kg} \mathrm{N}$ applied to the crops. On the basis of the above assumptions, and taking into account the rate of $\mathrm{N}$ supplied annually to the crops we estimated the gross and net soil $\mathrm{C}$ gain in $\mathrm{CO}_{2}$ equivalent (Table 3). Obviously, the hidden $\mathrm{C}$ cost is equal to zero for black locust, a legume specie that was not fertilized with $\mathrm{N}$. The $\mathrm{N}$ related $\mathrm{CO}_{2}$ emission ranged from $20 \%$ of gross $\mathrm{SOC}$ gain for willow, to $66 \%$ for miscanthus. Thus, the net SOC gain was positive for all the compared crops.

However, the number of years in which the SOC will continue to increase still has to be evaluated. As soon as the SOC reaches a new equilibrium, the hidden $\mathrm{C}$ cost of nitrogen fertilization will no longer be compensated by soil C sink. However, it is important to consider that at least $10 \mathrm{Mg}$ dry matter $\mathrm{ha}^{-1}$ year-1 will be still available for displacing fossil fuels. King et al. (2004) indicated that willow and miscanthus provide 25 and 36 times, respectively, as much energy as they consume in production. As Bransby et al. (1998) pointed out, SOC sequestration is a one-off benefit, while the benefit from replacing fossil fuels is continuous and cumulative.

Moreover, Olness et al. (2002) pointed out that $\mathrm{N}$ represents a critical aspect of soil $\mathrm{C}$ sequestration. The authors underlined that since $\mathrm{N}$ is about $9 \%$ of soil organic matter (SOM), a source of $\mathrm{N}$ is needed to allow the storage of SOC. Therefore, an increase of $0.1 \%$ in SOC for a layer of $0.15 \mathrm{~m}$, assuming bulk density of 1.2 and a nitrogen efficiency of $50 \%$, requires $328 \mathrm{~kg} \mathrm{~N}^{-1}$. Consequently, when the $\mathrm{N}$ embodied in soil organic matter is provided by industrial fertilizers, an environmental cost in terms of fossil energy used (and $\mathrm{CO}_{2}$ released) should be taken into account. Our findings provide evidence which contrasts with the assumptions of these authors. In fact, we found a very poor relationship between SOC and soil total nitrogen content (Figure 1).

Under our experimental conditions, the increase in SOC was not accompanied by a concomitant increase in soil N. In other words, with the perennial crops and the natural meadow, the SOC rose while the $\mathrm{N}$ content remained fairly constant; therefore, the $\mathrm{C}$ to $\mathrm{N}$ ratio increased rather than remained constant. It is worth noting that our energy crops have received little $\mathrm{N}$ supply, ranging from 60 to $120 \mathrm{~kg} \mathrm{~N} \mathrm{ha}^{-1} \mathrm{y}^{-1}$, and this is likely the reason for the fact that there was no increase in soil $\mathrm{N}$. However, we observed no increase in soil $\mathrm{N}$ content even for black locust; a nitrogen fixing crop not fertilized with $\mathrm{N}$. In fact, the $\mathrm{C}$ to $\mathrm{N}$ ratio of black locust in the $0.0-0.2 \mathrm{~m}$ soil layer, i.e. $8.74 \pm 0.77$, was in the observed range of the other species: 7.73-10.75 (data not shown).

Finally, our data of soil $\mathrm{C}$ and $\mathrm{N}$ content for woody species are in good agreement with Rau et al. (2009) who investigated soil C and $\mathrm{N}$ as affected by natural vegetation in the Great Basin of the US. These authors reported that the soil under tree microsites had higher $\mathrm{C}$ to $\mathrm{N}$ ratio than interspace microsites.

\section{Relationship between soil organic carbon and biomass yield}

The average annual dry matter yield of the compared species for the period 2002-2007 is shown in Figure 2. Under our experimental conditions, giant reed was a superior crop in terms of productivity, while the SRC of poplar and willow provided a modest biomass yield (Di Candilo et al., 2008). The relationship between the average dry matter yield and the SOC in the 0.0-0.2 m upper layer is shown in Figure 3. There is no significant relation between the harvested aboveground biomass of the crops and their SOC. Therefore, the productivity of the perennial energy crops is a poor predictor of SOC storage.

Normally, $\mathrm{C}$ is added to the soil by deposition and decay of plant dry

Table 3. Gross and net annual soil organic carbon gains for the 0.0-0.2 m soil layer, and nitrogen related $\mathrm{CO}_{2}$ emissions estimated on the basis of annual rates of nitrogen fertilization.

\begin{tabular}{lcccc} 
Crop & $\begin{array}{c}\text { Gross } \\
\text { SOC } \\
\text { gain } \\
\left(\mathrm{kg} \mathrm{CO}_{2} \mathrm{ha}^{-1} \mathrm{y}^{-1}\right)\end{array}$ & $\begin{array}{c}\text { Rates of } \\
\mathrm{N} \text { supply } \\
\left(\mathrm{kg} \mathrm{N} \mathrm{N}^{-1}\right)\end{array}$ & $\begin{array}{c}\mathrm{N} \text { related } \\
\text { GHG } \\
\text { emission } \\
\left(\mathrm{kg} \mathrm{CO}_{2} \mathrm{ha}^{-1} \mathrm{y}^{-1}\right)\end{array}$ & $\begin{array}{c}\text { Net SOC } \\
\text { gain } \\
\left(\mathrm{kg} \mathrm{CO}_{2} \mathrm{ha}^{-1} \mathrm{y}^{-1}\right)\end{array}$ \\
Willow & 7132 & 60 & 1435 & 5697 \\
Giant reed & 6234 & 120 & 2870 & 3364 \\
\hline Poplar & 6205 & 60 & 1435 & 4769 \\
Miscanthus & 4320 & 120 & 2870 & 1449 \\
\hline Black locust & 4232 & 0 & 0 & 4232 \\
Meadow & 3073 & 0 & 0 & 3073 \\
\hline
\end{tabular}

$\mathrm{N}$, nitrogen; SOC, soil organic carbon; GHG, greenhouse gas.

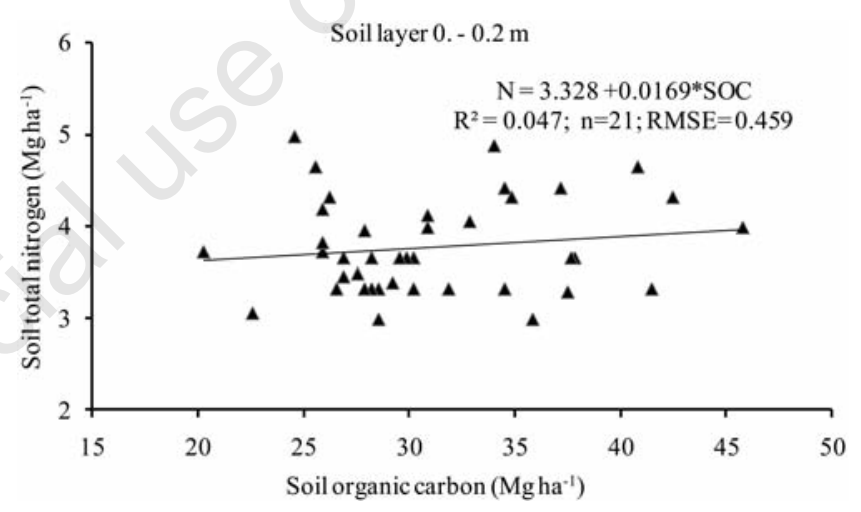

Figure 1. Relationship between soil organic carbon and soil total nitrogen in the 0.0-0.2 $\mathrm{m}$ soil layer.

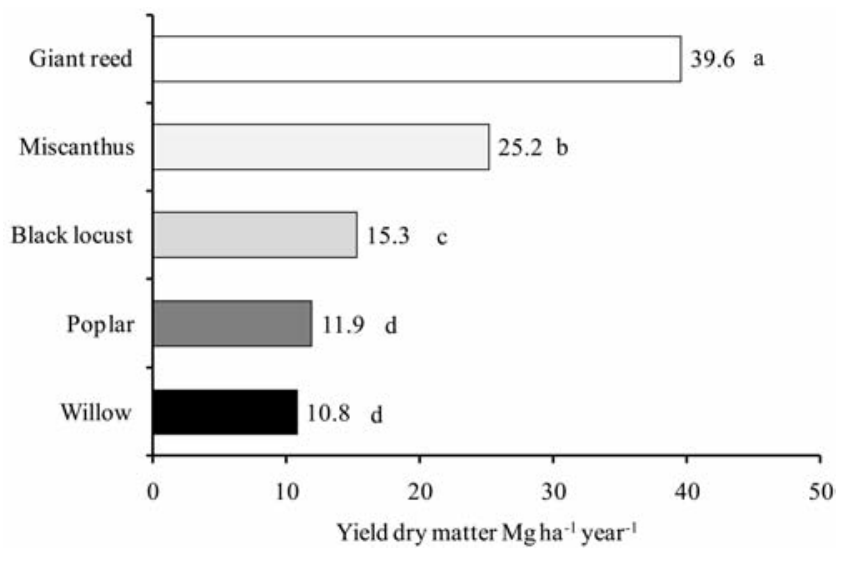

Figure 2. Average annual dry matter yield of the compared species for the period 2002-2007. Yields of biennially harvested species were halved to place them on an annual basis. Means sharing common letters are not statistically different for $\mathbf{P} \leq 0.05$ (Tukey test). ANOVA: species $\mathrm{P}<\mathbf{0 . 0 0 0 1}$; selected contrasts: giant reed $\boldsymbol{v s}$ other species $\mathrm{P}<\mathbf{0 . 0 0 0 1}$; herbaceous crops $v$ s woody crops $\mathrm{P}<0.0001$; poplar and black locust $v s$ willow $\mathrm{P}<0.0045$. Modified from Di Candilo et al., 2008. 


\section{References}

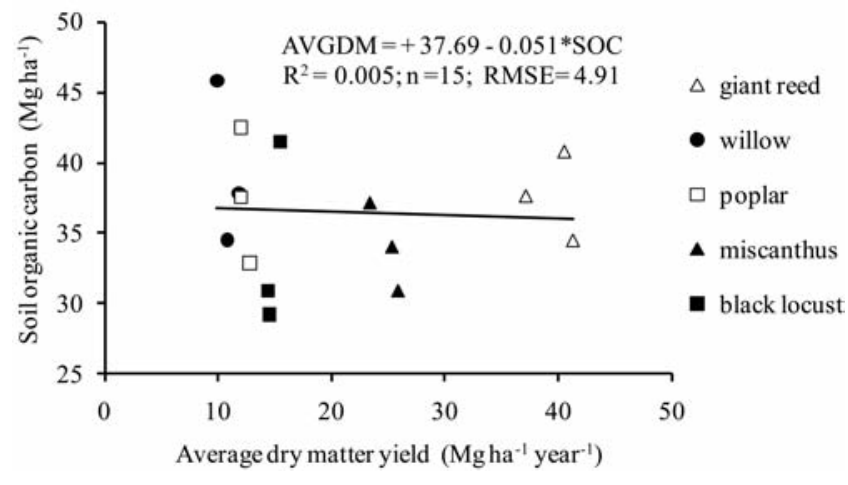

Figure 3. Relationship between average annual dry matter yield (2002-2007) and soil organic carbon in the upper $0.0-0.2 \mathrm{~m}$ soil layer. Data of individual crop species are shown.

matter on the soil surface and also by root senescence within the soil. It is important to point out that we have not measured the amount of $\mathrm{C}$ input to the soil with falling leaves and the fine root turnover. Therefore, we cannot infer that harvestable biomass is related to $\mathrm{C}$ input to the soil. Woody species normally lose all their leaves during the autumn, before the harvest of biomass which is performed every two years during the winter. Therefore, they provide abundant litter on the soil surface. On the contrary, giant reed and miscanthus tend to maintain most of their senesced leaves attached to the stems, which are consequently harvested every year, during the winter period. In addition, different plant species might have a different fine root turnover and composition. Thus, differences in harvestable biomass production could be compensated by the intrinsic attitude of the plant species to provide $\mathrm{C}$ input to the soil.

Our findings are partially in contrast with Liebig et al. (2008). These authors found a positive, but still weak, relationship between the harvested aboveground biomass of switchgrass (Panicum virgatum L.) and the annual change in SOC in several locations along the central and northern Great Plains of the USA.

\section{Conclusions}

The conversion of arable land into perennial energy crops provided a substantial SOC sequestration benefit for a 7-year period. However, the soil acts as a $\mathrm{C}$ sink only in the $0.0-0.20 \mathrm{~m}$ upper layer. When the hidden $\mathrm{C}$ cost of industrial $\mathrm{N}$ fertilizers is taken into account, the SOC gain is still substantial. Differences in biomass productivity are not associated with the rise in SOC. While the SOC increased, the total N content in the soil remained fairly constant among the different options for land use, including the nitrogen fixing crop black locust.

Our data are preliminary, however, and the number of years in which the SOC will continue to increase needs to be quantified, in particular for the herbaceous species giant reed and miscanthus, with a supposedly long duration of useful cropping cycle of 20 years or longer. But then a key question arises: at the end of the cropping cycle will the $\mathrm{C}$ stay there? If the soil is converted back to arable land, the benefit of $\mathrm{C}$ sequestration will probably be lost in a few years. On the contrary, if perennial energy crops could be rotated, avoiding deep soil tillage, the SOC storage will be assured. As Marland et al. (2001) pointed out, the permanence of sequestered $\mathrm{C}$ is a matter of liability, because it implies the commitment to long-term vigilance in the management of the captured $\mathrm{C}$.
Anderson-Texeira K.J., Davis S.C., Masters M.D., DeLucia E.H., 2009. Changes in soil organic carbon under biofuel crops. GCB Bioenergy 1:75-96.

Brandão M., Milà i Canalis L., Clift R., 2011. Soil organic carbon changes in the cultivation of energy crops: implications for GHG balances and soil quality for use in LCA. Biomass Bioenerg. 35:2323-2336.

Bransby D.J., McLaughlin, S., Parrish D.J., 1998. A review of carbon and nitrogen balances in switchgrass grown for energy. Biomass Bioenerg. 14:379-384.

Crutzen P.J., Mosier A.R., Smith K.A., Winiwarter W., 2008. N20 release from agro-biofuel production negates global warming reduction by replacing fossil fuels. Atmos. Chem. Phys. 8:389-395.

Ceotto E., Borrelli L., Marchetti R., Tomasoni C., 2006. Effect of integrated forage rotation and manure management systems on soil carbon storage. In: S.0. Petersen (ed.) 12th RAMIRAN Int. Conf. Technology for Recycling of Manure and Organic Residues in a Whole-Farm Perspective. DIAS report Plant production no.123, pp 29-32.

Di Candilo M., Ceotto E., Diozzi M., 2008. Comparison of 7 ligno-cellulosic biomass feedstock species: 6-years results in the Low Po Valley. In: P. Rossi Pisa (ed.) 10th Congr. European Society of Agronomy, Bologna, Italy Multi-functional Agriculture, Agriculture as a Resource for Energy and Environmental Preservation. Ital. J. Agron. 3(Suppl.3):481-482.

FAO, 2008. Biofuels: Prospects, Risks and Opportunities. The State of Food and Agriculture. FA0, Roma, Italy. Available from: http//www.fao.org/sof/sofa/index_en.html

Fargione J., Hill J., Tilman D., Polasky S., Hawthorne P., 2008. Land Clearing and the Biofuel Carbon Debt. Science 319:1235-1238.

Farrell A.E., Plevin R.J., Turner B.T., Jones A.D., O'Hare M., Kammen D.M., 2006. Ethanol can contribute to energy and environmental goals. Science 311:506.

Grigal D.F., Berguson W.E., 1998. Soil carbon changes associated with short-rotation systems. Biomass Bioenerg. 14:371-377.

Hansen E.M., Christensen B.T., Jensen L.S., Kristensen K., 2004. Carbon sequestration in soil beneath long-term Miscanthus plantations as determined by $13 \mathrm{C}$ abundance. Biomass Bioenerg. 26:97-105.

Kahle P., Beuch S., Boelcke B., Leinweber P., Schulthen H.R., 2001. Cropping of miscanthus in Central Europe: biomass production and influence on nutrients and soil organic matter. Eur. J. Agron. 15:171-184.

King J.A., Bradley R.I., Harrison R., Carter A.D., 2004. Carbon sequestration and saving potential associated with changes to the management of agricultural soils in England. Soil Use Manage. 20:394402.

Koh L.P., Ghazoul J., 2008. Biofuels, biodiversity, and people: Understanding the conflicts and finding opportunities. Biol. Conserv. 141:2450-2460.

Liebig M.A., Schmer M.R., Vogel K.P., Mitchell R.B., 2008. Soil Carbon Storage by Switchgrass Grown for Bioenergy. Bioenerg. Res. 1:215222.

Marland G., Fruit K., Sedjo R., 2001. Accounting for sequestered carbon: the question of permanence. Environ. Sci. Policy 4:259-268.

Nath A.J., Das G., Das A.K., 2009. Above ground standing biomass and carbon storage in village bamboos in North East India. Biomass Bioenerg. 33:1188-1196.

Olness, A., Lopez, D., Cordes, J., Sweeney, C., Mattson, N., Voorhees, W.B., 2002. Application of a Management Decision Aid for Sequestration of Carbon and Nitrogen in Soil. In: J.M. Kimble, R. 
Lal and R.F. Follett (eds.) Agricultural Practices and Policies for Carbon Sequestration in Soil. Lewis Publisher, CRC press LLC, Boca Raton, FL, USA, pp 245-253.

Page A.L., Miller R.H., Keeney D.R., 1982. Methods of soil analysis. Part 2. 2nd ed. Agron. Monogr. 9. ASA and SSSA, Madison, WI, USA.

Payne W.A., 2010. Are biofuels antithetic to long-term sustainability of soil and water resources? Adv. Agron. 105:1-46.

Paustian K., Andren 0, Janzen H.H., Lal R., Smith P., Tian G., Tiessen H., Van Nordwijk M., Woomer P.L., 1997. Agricultural soils as a sink to mitigate CO2 emissions. Soil Use Manage. 13:230-244.

Rau B.M., Johnson D.W., Blank R.R., Chambers J.C., 2009. Soil carbon and nitrogen in a Great Basin pinyon-juniper woodland: Influence of vegetation, burning, and time. J. Arid Environ. 73:472-479.

Richter D.D., Hofmockel M., Callaham M.A. Jr., Powlson D.S., Smith P., 2007. Long-term soil experiments: keys to managing earth's rapidly changing ecosystems. Soil Sci. Soc. Am. J. 71:266-279.

Righelato R., Spracklen D.V., 2007. Carbon Mitigation by Biofuels or by Saving and Restoring Forests? Science 317:902.

Rootzen J.M., Berndes G., Ravindranath N.H., Somashekar H.I, Murty I.K., Sudka P., Ostwald M., 2010. Carbon sequestration versus bioenergy: A case study from South India exploring the relative land-use efficiency of two options for climate change mitigation. Biomass Bioenerg. 34:116-123.

Rowe R.L., Street N.R., Taylor G., 2009. Identifying potential environ- mental impacts of large-scale deployment of dedicated bioenergy crops in the UK. Renew. Sust. Energ. Rev. 13:271-290.

SAS 1989. User's Guide. 4th ed., SAS Inst. Inc., Cary, NC, USA.

Searchinger T., Heimlich R., Houghton R.A., Dong F., Elobeid A., Fabiosa J., Tokgoz S., Hayes D., Yu T.H., 2008. Use of U.S. croplands for biofuels increases greenhouse gases through emissions from landuse change. Science 319:1238-1240.

Schlesinger W.H., 1999. Carbon and Agriculture: Carbon Sequestration in Soils. Science 284,5423.2095.

Schlesinger W.H., 2000. Carbon sequestration in soils: some caution amidst optimism. Agr. Ecosyst. Environ. 82:121-127.

Soil Survey Staff 2003. Keys to Soil Taxonomy. 9th ed. USDA-Natural Resources Conservation Service, Washington, DC, USA.

Tilman D., Socolow R., Foley J.A., Hill J., Larson E., Lynd L., Pacala S., Reilly J., Searchinger T., Somerville C., Williams R., 2009. Beneficial Biofuels-The Food, Energy, and Environment Trilemma. Science 325:270-271.

Tomasoni C, Borrelli L, Ceotto E., 2011. Effect of integrated forage rotation and manure management on yield, nutrient balance and soil organic matter. Ital. J. Agron. 6:e10.

West T.O., Post W.M., 2002. Soil organic carbon sequestration rates by tillage and crop rotation: a global data analysis. Soil Sci. Soc. Am. J. 66:1930-1946. 